\title{
Transformasi Berkelanjutan Berbasis Sumber Daya Lokal: Sebuah Refleksi Penelitian Aksi Partisipatif terhadap Perempuan di Akar Rumput, Papua dan Papua Barat
}

\section{Selviana Yolanda ${ }^{1}$}

Peneliti

\begin{abstract}
Abstrak: Tulisan ini adalah refleksi atas penelitian aksi partisipatif bersama perempuan Papua dan Papua Barat. Melihat kembali dan mengakui sejarah bangsa Papua merupakan langkah penting untuk rekonsiliasi dan pemulihan kolektif di Papua. Karenanya, tulisan diawali dengan ulasan ringkas tentang latar belakang sejarah dan situasi konflik di Papua. Keluasan dan menyejarahnya kekerasan yang dialami perempuan Papua memberi gambaran akan pentingnya metode penelitian yang dapat memulihkan dan memberdayakan perempuan korban kekerasan di Papua dan Papua Barat. Akhirnya, pendekatan yang berasal dari akar rumput beserta catatan-catatan kritis dan rekomendasi dari riset aksi partisipatif sangat perlu diperhatikan oleh para penyusun kebijakan dan berbagai stakeholder yang terkait dalam perencanaan dan inisiatif pembangunan di Papua.

Kata Kunci: Perempuan, Papua, Papua Barat, Penelitian Aksi Partisipatif, refleksi
\end{abstract}

Abstract: The article is a reflection on the Participative Action Research done with the Papuan and West Papuan women. Looking back and acknowledging the history of Papuans is an important step for reconciliation and collective healing in Papua. Because of that, this article starts with a brief review about the historical background and conflict situation in Papua. The breadth and history of violence experienced by Papuan women show how important is a research method which is able to heal and empower women victims of violence in Papua and West Papua. Finally, an approach coming from the grass-root along with critical notes and recommendations from the research is very much needed to be considered by policy makers and various related stakeholders in the planning and development initiative in Papua.

Key Words: Women, Papua, West Papua, Participative Action Research, reflection

Korespondensi penulis:

Selviana Yolanda

E-mail: selviana.yolanda@gmail.com

\footnotetext{
1 Terlibat dalam pendokumentasian dan riset-riset tentang perempuan dan konflik di Papua, dalam kurun waktu 2009-2017.
} 


\section{Pendahuluan}

Tulisan ini berdasarkan pada refleksi penulis ketika melakukan penelitian aksi partisipatif bersama perempuan Papua dan Papua Barat. Kesempatan ini luar biasa, karena penulis sendiri belum sempat berbagi kisah tentang pandangan dan pengalaman penulis bersentuhan dengan isu-isu kemanusiaan, khususnya kondisi perempuan dalam situasi konflik di Papua. Tulisan dimulai dengan meletakkan ulasan ringkas tentang latar belakang sejarah dan situasi konflik di Papua, sebagai landasan pikir membahas Papua. Penulis yakin bahwa melihat kembali dan mengakui sejarah bangsa Papua merupakan langkah penting untuk rekonsiliasi dan pemulihan kolektif di Papua.

Bagian kedua tulisan berisi uraian pengalaman dalam melakukan pendokumentasian kasus-kasus kekerasan dan pelanggaran HAM di Papua, sebagai gambaran tentang keluasan dan menyejarahnya kekerasan yang dialami perempuan Papua, serta catatan kritis tentang pemulihan hak-hak korban yang tidak berjalan baik oleh pemerintah Indonesia. Program-program pemulihan yang selama ini berjalan banyak dimotori oleh aktivis Lembaga Swadaya Masyarakat, gereja atau kelompok korban sendiri. Meski demikian, masih banyak korban-terutama perempuan-yang hidup dalam rasa sakit, trauma dan tetap diam menyimpan semua pengalaman mereka karena tidak ada pihak yang mau mendengarkan.

Bagian ketiga tulisan, penulis menyajikan pengalaman penulis dan teman-teman di Papua ketika melakukan penelitian aksi partisipatif. Meskipun ini bukan sebuah pendekatan ideal, namun setidaknya melalui metode ini, kami belajar mengembangkan sebuah penelitian sekaligus pemulihan dan pemberdayaan bagi perempuan Papua yang menjadi narasumber, yang umumnya memiliki atau setidaknya berjumpa dengan 
pengalaman kekerasan dalam hidup mereka, juga hal yang sama dialami oleh keluarga dan komunitas mereka. Secara sederhana kami mengembangkan metode yang mudah digunakan di akar rumput, dan mendorong partisipasi narasumber dan komunitas untuk melakukan perubahan yang lebih baik.

Persoalan-persoalan yang dikemukakan dalam diskusi-diskusi kemudian menjadi bahan aksi komunitas dan alat advokasi yang kemudian disampaikan kepada aparat pemerintah, mulai dari level kampung, distrik, kabupaten hingga provinsi dan pemerintah pusat. Namun, karena keterbatasan sumber daya yang kami miliki, penelitian ini tidak bisa menjangkau lebih banyak korban dan komunitas. Penelitian aksi partisipatif selama dua tahun terakhir di Papua (2015-2017) dibangun atas kerja bersama Papuan Women Working Group (PWG) yang beranggotakan berbagai organisasi perempuan, organisasi HAM dan individu yang konsen dengan isu Papua. ${ }^{2}$

\section{Konteks Papua: Sejarah dan Situasi Konflik yang Tak Kunjung Berakhir}

Nama Papua pertama kali dikenal dari catatan penjelajah Portugis, Jorge de Meneses, yang mencapai pantai barat laut pulau New Guinea pada tahun 1526; ia menyebut pulau tersebut Ilhas dos Papuas. Nama Papua Barat sendiri mulai dikenal luas setelah Kongres I Dewan Papua tahun 1961, menetapkan "Papua Barat" sebagai nama wilayah itu dan “Tanah Airku Papua” sebagai lagu kebangsaan. Setelah Indonesia mengambil alih wilayah ini pada tahun 1963, nama Papua diganti menjadi Irian Barat; dan pada tahun 1969 berubah menjadi Irian Jaya. Orang Papua tidak menyukai terminologi Irian Jaya, bagi

\footnotetext{
2 PWG dibentuk atas inisiasi dari Asia Justice and Rights (AJAR), Elsham Papua, KPKC GKI Tanah Papua, Humi Inane Wamena, Belantara Papua, Sorong, SP KAME Merauke, Ibu Frida Klasin (DPR Papua Barat) dan Alm. Ibu Mintje Roembiak (aktivis perempuan Papua dan antropolog dari UNCEN), dalam sebuah pertemuan di bulan November 2015.
} 
mereka ini menjadi simbol penghinaan Indonesia pada kebudayaan Papua. Sehingga ketika masa reformasi pada 1998, rakyat Papua mulai bersuara dan meminta pergantian nama provinsi ini kembali menjadi Papua atau Papua Barat. Kesempatan itu baru datang pada 1 Januari 2002, ketika Undang-Undang Otonomi Khusus Papua diberlakukan, nama Papua resmi kembali digunakan (Rathgeber 2006, 68-69).

Secara adat, tanah Papua terdiri dari sekitar 250 suku yang terbagi dalam tujuh wilayah adat, yaitu: (1) Wilayah adat Mamta yang mencakup 86 suku dan mendiami wilayah Jayapura sampai Memberamo; (2) Wilayah adat Sairei mencakup 31 suku yang mendiami wilayah-wilayah di sekitar Teluk Cendrawasih, Biak, Yapen Waropen; (3) Wilayah adat Bomberai meliputi 52 suku yang mendiami daerah-daerah di sekitar kepala burung termasuk Bintuni, Manokwari dan Sorong; (4) Wilayah adat Domberai sebanyak 18 suku yang bermukim di wilayah Fak-fak Teluk Arguni (Kaimana) dan berbatasan di sebelah utara dengan Teluk Bintuni; (5) Wilayah adat Anim-Ha membawahi 29 suku di wilayah Selatan Papua yang mendiami wilayah Merauke, Digoel, Asmat, Mappi, Muyu dan Mandobo; (6) Wilayah adat La-Pago sebanyak 19 suku yang bermukim di Wamena, Tiom hingga Oksibil; serta, (7) Wilayah adat Me Pago yang terdiri dari 13 suku di Nabire hingga suku yang bermukim di sekitar danau Paniai, Danau Tigi dan Danau Tege serta wilayah Puncak Jaya.

Dari sudut karakteristik budaya, mata pencaharian dan pola hidup sehari-hari, orang asli Papua dibagi menjadi tiga kelompok besar, yaitu penduduk yang bermukim di daerah pegunungan atau pedalaman, penduduk yang hidup di daerah rawa di dataran rendah antara pegunungan dan penduduk yang hidup di daerah pantai atau pesisir. Pola kepercayaan dan spiritualitas masyarakat Papua menyatu dalam segala aspek kehidupan, mereka memiliki pandangan dunia yang terkait erat kaitannya satu sama lain 
antara dunia yang material dan spiritual atau yang sekuler dan saklar, keduanya berfungsi bersama-sama.

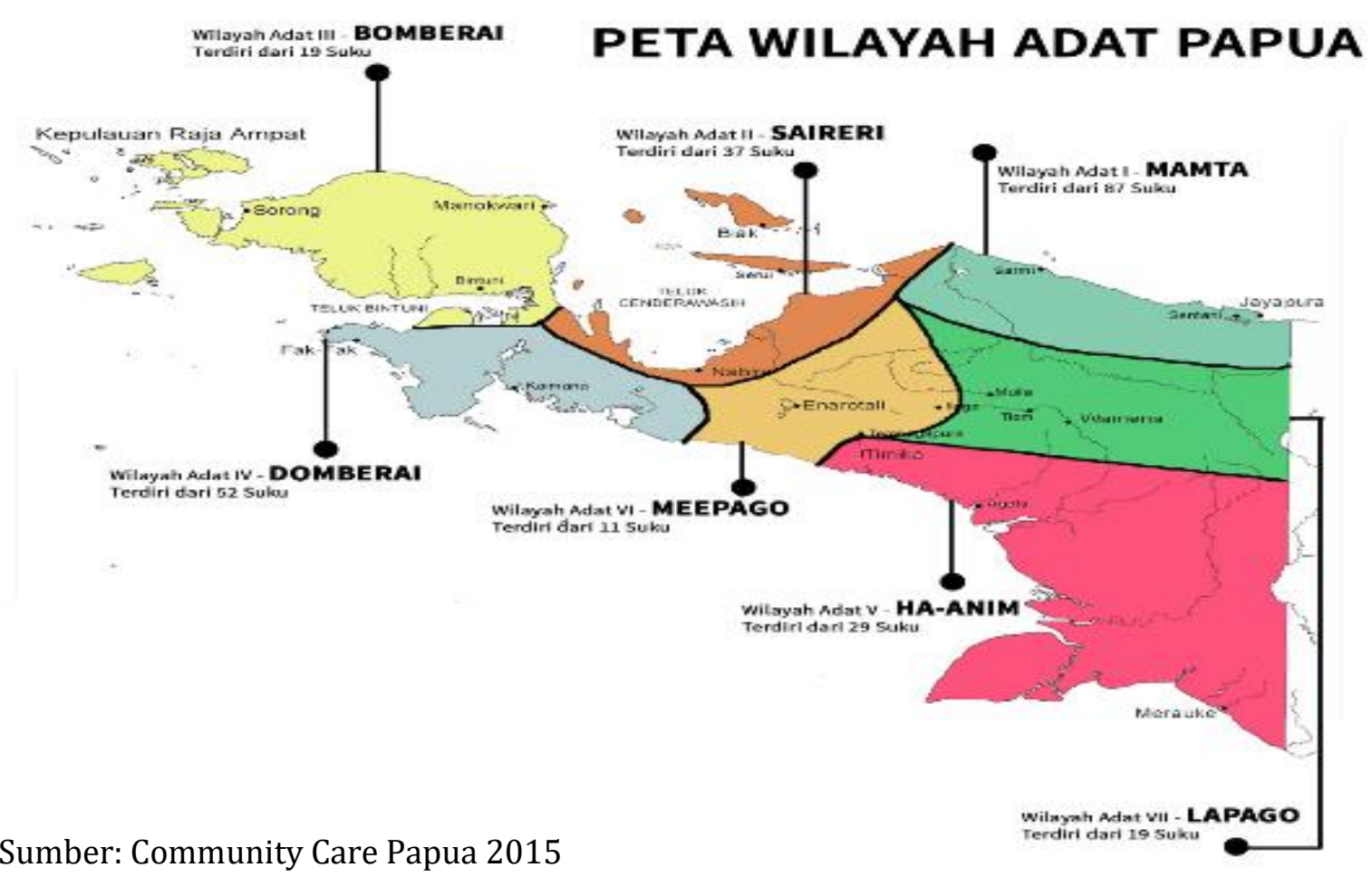

\section{Gambar 1. Tujuh Wilayah Adat Papua}

Ketika Belanda menyerahkan wilayah Hindia Belanda kepada Indonesia pada tahun 1949, Papua masih di bawah sistem pemerintahan Belanda dan tidak termasuk ke dalam wilayah Republik Indonesia. Presiden Soekarno kemudian melancarkan diplomasi internasional dan menggalang dukungan negara-negara dunia terutama Amerika Serikat. Hasilnya, pada Agustus 1962 digelar kesepakatan New York (New York Agreement) yang memutuskan penyerahan pemerintahan di Papua dari Belanda kepada Otoritas Eksekutif Sementara PBB (UNTEA) pada Oktober 1962, dan setahun kemudian, 1 Mei 1963, Papua diserahkan kepada pihak Indonesia untuk kemudian digelar penentuan jajak pendapat rakyat (referendum), apakah menjadi bagian dari Indoensia atau berdiri sendiri sebagai suatu bangsa merdeka 
Pada tahun 1961, setahun sebelum Kesepakatan New York digelar, Presiden Soekarno telah mulai melancarkan agresi militer Indonesia ke Papua dengan dengan semboyan Trikora. Soekarno menunjuk Mayor Jenderal Soeharto untuk memimpin operasi militer, dengan sandi operasi Komando Mandala, 1962. Pada saat yang bersamaan, tahun 1961, pemerintah Belanda mengambil langkah-langkah untuk mendorong orang Papua membentuk pemerintahan sendiri, melalui pembentukan sebuah dewan rakyat yang diberi nama Nieuw-Guinea Raad. Dalam Kesepakatan New York dinyatakan bahwa "hak semua orang dewasa, laki-laki dan perempuan, bukan warga negara asing, untuk berpartisipasi dalam tindakan menentukan nasib sendiri yang dilaksanakan sesuai dengan praktik internasional"; namun pada kenyataannya, hanya 1.026 lebih tokoh adat Papua (laki-laki, dari 815.000 lebih rakyat), yang ditunjuk oleh pemerintah Indonesia untuk ikut Penentuan Pendapat Rakyat (Pepera) tahun 1969. Sudah bisa diduga hasilnya suara bulat mendukung integrasi Papua ke Indonesia.

Sebelum dan setelah pelaksanaan Pepera, aksi kekerasan oleh militer Indonesia di Papua semakin merebak dan menyasar orang-orang yang kritis terhadap proses Pepera. Mereka yang menjadi korban mulai dari guru, warga sipil, sampai kelompok bersenjata. Represi ini juga berkontribusi pada penguatan gerakan perlawanan bersenjata, dengan pembentukan kelompok yang dikenal sebagai Organisasi Papua Merdeka (OPM) pada tahun 1965 (KKPK 2014, 44).

Pada tahun 2001, merespon aspirasi masyarakat yang menuntut kemerdekaan, pemerintah Indonesia memberi status otonomi khusus kepada Papua yang ditetapkan melalui Undang-Undang No. 21 Tahun 2001. Undang-Undang ini memberikan kerangka penyelenggaraan pemerintahan sendiri bagi orang Papua dan ruang pengakuan bahwa pelaksanaan pembangunan di Papua selama ini belum sepenuhnya memberikan rasa 
keadilan, tidak menghadirkan kesejahteraan bagi rakyat Papua dan masih rendahnya penghormatan atas hak asasi manusia. Undang-Undang ini mengatur penegakan hak orang asli Papua melalui tindakan: perlakuan khusus sementara (affirmative action), perlindungan (protection) dan pemberdayaan (empowerment). Pada pasal 47 secara khusus mengatur kewajiban pemerintah untuk memajukan, memberdayakan dan melindungi kaum perempuan supaya sejajar dengan laki-laki.

Dalam kenyataan, mandat otonomi khusus Papua tidak dijalankan secara konsisten oleh pemerintah Indonesia. Pada tahun 2003, Presiden Megawati Soekarno Putri justru menetapkan keputusan pemekaran Papua menjadi Provinsi Papua dan Papua Barat yang bertentangan dengan Undang-Undang No. 21 Tahun 2001 yang menyebut bahwa kesatuan masyarakat asli Papua di Tanah Papua tidak bisa dipisahpisahkan.

Meski secara faktual Papua ditetapkan sebagai wilayah dengan prioritas keamanan yang tinggi, namun belum ada data resmi yang dikeluarkan oleh pemerintah Indonesia mengenai status keamanan di Papua. Dalam kenyataan sehari-hari, operasi keamanan di Papua terus berjalan hingga hari ini. Tidak ada informasi yang pasti mengenai jenis-jenis operasi, jumlah pasukan, baik polisi dan tentara maupun tujuan pelaksanaan operasi. Rakyat Papua menyaksikan jumlah aparat keamanan dan pos-pos terus bertambah, pengembangan markas batalyon dan suplai pasukan keamanan dari luar Papua terus terjadi setiap ada insiden kekerasan.

Prioritas keamanan di Papua begitu tinggi, namun keamanan masyarakat tidak terjamin. Di media massa sering disebutkan informasi tentang penyiksaan, penembakan sewenang-wenang, penangkapan dan penahanan terhadap masyarakat sipil dan aktivis Papua. Isu Papua sudah menjadi perhatian negara-negara di kawasan Pasifik dan 
internasional. Permasalahan kemanusiaan di Papua juga menjadi topik pembahasan dalam berbagai pertemuan komite HAM PBB (UNGA 2008) dan perhatian utama kunjungan pelapor khusus PBB ke Indonesia. ${ }^{3}$

\section{Situasi Hidup Perempuan Papua: Berhadapan dengan kekerasan negara,}

\section{kekerasan domestik dan diskriminasi budaya}

Kekerasan berbasis gender mengacu pada setiap tindakan yang berdasarkan perbedaan jenis kelamin yang berakibat kesengsaraan atau penderitaan perempuan secara fisik, seksual atau psikologis termasuk ancaman terjadinya perbuatan tersebut, pemaksaan atau perampasan kebebasan secara sewenang-wenang, baik yang terjadi di ruang publik maupun dalam kehidupan sehari-hari (Rekomendasi No. 19 Komite CEDAW)

Situasi konflik bersenjata semakin memperburuk ketidaksetaraan gender yang terjadi dalam kehidupan sosial-budaya masyarakat dan menempatkan perempuan pada risiko paling rentan dari berbagai bentuk kekerasan berbasis gender, baik yang dilakukan oleh aparat negara maupun non-negara. Perempuan Papua diperhadapkan pada kondisi yang membuat mereka menjadi sasaran utama kekerasan. Sejumlah perempuan Papua mengalami kekerasan seksual selama diberlakukan pendekatan keamanan di Papua. Pada saat bersamaan perempuan Papua juga diperhadapkan dengan diskriminasi dalam adat budaya, yang mengakibatkan kekerasan terhadap perempuan terus berlangsung.

Konflik dan pendekatan pembangunan telah membuat perubahan sosial dan menyebabkan pergeseran pola relasi antara perempuan dan laki-laki. Dalam situasi ini, marak terjadi kekerasan dalam rumah tangga (KDRT) seperti poligami dan perselingkuhan, sebagai akibat dari meningkatnya perilaku konsumtif dan konsumsi

\footnotetext{
${ }^{3}$ Kata Sambutan UN High Commissioner for Human Rights (KTHAM/Komisi Tinggi Hak Asasi Manusia) Zeid Ra'ad Al Hussein pada Konferensi Pers untuk Misi Kunjungannya ke Indonesia, Jakarta, 7 Februari 2018; Pengamatan Awal dari Pelapor Khusus tentang Hak atas Pangan, Hilal Elver, dalam misinya ke Indonesia 9-18 April 2018.
} 
minuman keras, terutama di kalangan para lelaki yang memiliki akses besar pada danadana Otsus. Semua kasus kekerasan yang terjadi tidak lepas dari peran dan tanggung jawab negara. ${ }^{4}$

\section{- Akses pada Keadilan dan Pemulihan bagi Korban}

Dampak berlanjut yang tidak tertangani selama bertahun-tahun menyebabkan perempuan mengalami peminggiran dari segala aspek kehidupan, menderita sakit dan hidup dalam kondisi miskin. Perempuan kehilangan harta benda dan sumber penghidupan karena konflik, dan hal ini diperparah oleh sistem budaya dalam masyarakat di mana perempuan tidak memiliki hak atas tanah. Sementara dalam budaya Papua, mengerjakan kebun, memelihara ternak dan menyiapkan makanan merupakan tugas utama perempuan, sehingga hilangnya harta benda merupakan hal yang menyedihkan buat mereka.

Berikut penulis mengutip kisah Mama Naomi yang tinggal di sebuah kampung di Distrik Genyem, Kabupaten Jayapura. Dalam sebuah dengar kesaksian publik yang diselenggarakan oleh KKPK di Jakarta pada November 2013 (KPKK 2014, 154-155), Mama Naomi menceritakan kekerasan seksual yang dilakukan oleh aparat keamanan ketika menggelar operasi keamanan di kampungnya pada tahun 1980-an. Mama Naomi

\footnotetext{
${ }^{4}$ Lihat Laporan Stop Sudah! Kesaksian Perempuan Korban Kekerasan dan Pelanggaran HAM, mencatat selama periode 1963-2009, setidaknya 138 orang perempuan menjadi korban kekerasan negara. Bentuk kekerasan yang terjadi: pembunuhan, penghilangan paksa, penembakan, percobaan pembunuhan, penahanan sewenang-wenang, penganiayaan dan penyiksaaan, pengungsian paksa serta bentuk kekerasan seksual berupa penyiksaan seksual, pemerkosaan, percobaan perkosaaan, perbudakan seksual, eksploitasi seksual dan pemaksaan penggunaan alat kontrasepsi; kedua, Kekerasan Dalam Keluarga, ditemukan sebanyak 98 orang perempuan mengalami bentuk kekerasan fisik, psikis dan seksual dalam bentuk: poligami/selingkuh, penganiayaan, penelantaran ekonomi, perkosaan dalam perkawinan, kekerasan psikis, pembatasan ruang gerak dan pemaksaan kawin. Dalam tipologi ini juga dicatat pula perempuan menderita HIV/AIDS karena tertular dari suami atau pasangannya; kekerasan berlapis, yaitu satu bentuk kekerasan tertentu yang berdampak pada bentuk-bentuk kekerasan lainnya. Setidaknya 14 orang perempuan menjadi korban kekerasan. Ditemukan juga 11 kasus kekerasan terhadap perempuan, yang terjadi dalam konteks perang suku dan eksploitasi sumber daya alam.
} 
pernah dijadikan 'umpan' oleh tentara yang mencari keberadaan suaminya yang dituduh OPM dan lari ke hutan. Ketika tidak menemukan suaminya, ia dibawa ke pos tentara dan mengalami kekerasan seksual dari tentara di pos. Mendengar kejadian yang dialami Mama Naomi, akhirnya suami meninggalkan dia dan menikah dengan perempuan lain. Mama Naomi kemudian menjadi peserta dalam penelitian aksi partisipatif yang difasilitasi ELSHAM Papua dan Asia Justice and Rights. Dalam sebuah sesi dia mengungkapkan: "Mama sedih karena mengalami hal ini. Mama sudah mengalami kekerasan untuk menyelamatkan suami, tapi akhirnya bapa meninggalkan mama dan menikah dengan perempuan lain."

Beberapa tahun yang lalu, anak perempuan Mama Naomi meninggal dunia karena sakit paru-paru. Saat ini Mama Naomi mengasuh dua cucu perempuan dari anaknya yang telah meninggal dunia. Sementara bantuan dari pemerintah melalui dana-dana Rencana Strategis Pembangunan Kampung (RESPEK) tidak pernah didapat Mama Naomi.

"karena masyarakat melihat bahwa Mama termasuk dalam (lingkaran kegiatan) OPM sehingga apa yang Mama alami itu sudah risiko... Mama telah menunjukkan bahwa militer bertanggung jawab atas apa yang terjadi pada Mama. Mama telah kehilangan martabat Mama... Pemerintah kampung yang mempunyai dana RESPEK bisa bantu Mama, tapi karena Mama sudah begini, jadi mereka tidak mau bantu" (Wandita 2015).

Pada Maret 2017, ketika tim PWG menemui Mama Naomi untuk melihat kondisi dan perkembangan kehidupannya, Mama bercerita bahwa ketika suaminya meninggal dunia, Mama tidak bisa mengakses tanah dan rumah yang selama ini mereka tempati. Ini terjadi karena kedua properti tersebut diambil alih oleh keluarga dari suaminya dengan alasan Mama tidak memiliki anak laki-laki.

"Sa sakit, sa rasa sakit tulang ini sudah sa biasa rasa sakit di belakang, sa pikul noken pedis setengah mati...tapi sa tidak ke rumah sakit, sa minum ramuan kumis kucing, sa rebus...sa tidak bisa ke rumah sakit sa rasa malu hati... Setelah bapa meninggal,keluarganya ambil kembali tanah, rumah sudah mereka kasih rubuh. Alasannya mama tra punya anak. Mama rencana mau balik ke 
kampung, tinggal dengan adik-adik, mereka mau bikin rumah untuk mama dan cucu dua ini tinggal" (PWG 2017, 44).

Kisah Mama Naomi memberi gambaran kepada kita betapa perempuan mengalami kekerasan sistematis dan berlapis selama konflik dan pascakonflik. Selain Mama Naomi, masih banyak perempuan Papua yang hingga sekarang mengalami cacat karena kena tembakan, mengalami gangguan reproduksi karena kekerasan seksual yang dialami, masih dikucilkan dan mendapat stigma negatif dari keluarga dan masyarakat. Akibat stigma yang terus berkembang mereka mengalami diskriminasi dalam hal mendapatkan bantuan dan layanan publik dari negara karena dianggap "separatis". Dampak stigma negatif tidak saja dialami orang tua namun menurun hingga ke anakanak; mereka kesulitan mendapatkan akses pekerjaan di instansi pemerintah.

Akses korban terhadap keadilan masih sangat jauh dari harapan. Hingga sekarang, belum ada satupun kasus kekerasan terhadap perempuan selama masa konflik yang diproses secara hukum. Tidak ada pengakuan atas apa yang dialami korban, meskipun sudah begitu banyak catatan, laporan, dan berbagai kesaksian tentang pengalaman kekerasan yang mereka alami. Korban, keluarga dan komunitas tetap hidup dalam trauma dan penderitaan.

\section{- Akses pada Layanan Pendidikan, Kesehatan dan Ekonomi}

Di wilayah-wilayah pegunungan, tempat di mana mayoritas orang-orang asli Papua banyak bermukim, akses terhadap layanan-layanan dasar seperti kesehatan, pendidikan, pasar, minim akibat terbatasnya infrastruktur yang tersedia. Kalaupun ada tenaga medis, obat-obatan tidak tersedia. Demikian pula dalam bidang pendidikan. Meskipun ada gedung sekolah, tidak ada pengajar. Situasi ini terutama karena pembangunan oleh pemerintah Indonesia tidak mampu mencapai wilayah-wilayah tersebut. Hal lain karena pendekatan kebijakan keamanan, di mana wilayah pegunungan merupakan daerah- 
daerah operasi militer Indonesia, sehingga pelayanan publik kepada masyarakat tidak berjalan.

Kondisi ini diperburuk dengan terbatasnya ruang gerak perempuan karena situasi tidak aman, juga sarana transportasi yang mahal sehingga menutup akses perempuan terhadap perawatan kesehatan lebih lanjut, yang umumnya tersedia dalam jumlah terbatas di ibukota kabupaten. Akibatnya paling dirasakan oleh perempuan dan anak. Perempuan berada pada risiko besar mengalami gangguan kesehatan reproduksi, mengidap infeksi yang ditularkan secara seksual, termasuk HIV/AIDS, serta anak-anak yang menderita kekurangan gizi bahkan hingga menyebabkan kematian.

Perempuan-perempuan Papua yang hidup di kampung-kampung di luar zona konflik, juga mengalami dampak akibat kurangnya layanan kesehatan yang memadai. Selain itu, mereka menghadapi tantangan kesulitan ekonomi yang meningkat dan rentan terhadap kekurangan pangan. Banyak perempuan menjadi pencari nafkah utama bagi keluarga, namun mereka sering dihadapkan pada situasi yang sulit dalam mengakses sarana transportasi, tempat yang layak untuk jualan di pasar dan program bantuan dari pemerintah.

\section{Pendokumentasian Kisah Kehidupan Perempuan Papua}

Pada tahun 2009-2010, ketika menjadi staf di Komisi Nasional Anti Kekerasan terhadap Perempuan (Komnas Perempuan) penulis berkesempatan menjadi anggota kelompok kerja pendokumentasian yang melakukan pengumpulan data kekerasan \& pelanggaran HAM terhadap perempuan di Papua (Komnas Perempuan, Pokja Perempuan MRP dan ICTJ 2010). Pendokumentasian ini dilaksanakan bekerja sama dengan Majelis Rakyat 
Papua (MRP), dua belas Organisasi Perempuan dan HAM beserta aktivis-aktivis perempuan di Tanah Papua ${ }^{5}$. Kami merampungkan sebuah laporan yang menjangkau lebih dari 260 kesaksian perempuan Papua. Sejumlah temuan dan rekomendasi dihasilkan telah disampaikan kepada berbagai pihak, terutama pemerintah provinsi di Papua dan Papua Barat, tokoh-tokoh agama dan masyarakat umum; serta disampaikan kepada pemerintah nasional di Jakarta dalam berbagai dialog dan pertemuan perihal kebijakan dengan instansi-instansi terkait. Sebagai tindak lanjut dari penyusunan laporan, tim kerja juga menyusun Peraturan Daerah Khusus Papua (Perdasus) No. 1 Tahun 2011 tentang Pemulihan Hak Perempuan Papua Korban Kekerasan dan Pelanggaran HAM.6 Meskipun hingga kini, Perdasus tersebut belum diimplementasikan oleh pemerintah Provinsi Papua.

Pasca-keluarnya Laporan Stop Sudah!, berbagai organisasi perempuan di Papua, melanjutkan kerja-kerja pendokumentasian kasus kekerasan terhadap perempuan, melakukan advokasi Perdasus No. 1 Tahun 2011, menyusun laporan kondisi hak asasi perempuan Papua untuk pelaporan internasional, melakukan berbagai pendekatan khusus untuk pemulihan perempuan dan regenerasi gerakan dengan kelompok perempuan muda. Meski, dalam evaluasi tujuh tahun setelah publikasi Laporan Stop Sudah! tercatat bahwa negara belum menjalankan mandatnya untuk pemulihan hak perempuan korban kekerasan di Papua. Progam-progam pemulihan yang dijalankan masih merupakan inisiatif dari organisasi masyarakat sipil dan gereja. ${ }^{7}$

\footnotetext{
${ }^{5}$ Kelompok Kerja Pendokumentasian terdiri dari: Mitra Perempuan Manokwari, Belantara Papua Sorong, SKP Jayapura, SKP Merauke, SKP Wamena, Humi Inane Wamena, Debar Biak, Primari Nabire, Jaringan Perempuan Mimika, JKPIT Timika, LP3AP Jayapura, KPKC GKI Tanah Papua.

${ }_{6}^{6}$ Pembentukan Perdasus Papua sesuai dengan mandat Undang-Undang Otonomi Khusus Papua No. 21 Tahun 2001, pasal 1 (i).

${ }^{7}$ Evaluasi dilaksanakan di Jayapura pada Juni 2017, bersama organisasi perempuan, aktivis perempuan dan perwakilan korban di Tanah Papua.
} 
Melihat situasi dan kondisi Papua yang begitu kompleks dan carut marut dengan berbagai persoalan, terutama kondisi keamanan dan kasus-kasus pelanggaran HAM, Papua Women Working Group (PWG) terdorong untuk mengembangkan sebuah pendekatan yang inovatif melalui penelitian aksi partisipatif bagi perempuan Papua, yang bertujuan untuk mendengarkan sekaligus menguatkan suara-suara perempuan asli Papua. Penulis membantu PWG untuk mengasistensi para tim fasilitator muda yang melakukan riset partisipatif di lima wilayah di Papua. ${ }^{8}$ Sebagai pengantar refleksi tentang metode ini, penulis coba mengemukakan beberapa pemikiran terkait penelitian aksi partisipatif.

\section{Penelitian Aksi Partisipatif: Sebuah pendekatan pemberdayaan \& penguatan menuju perubahan komunitas}

Secara prinsip, penelitian aksi partisipatif sebagai sebuah metode pendekatan memiliki semangat membuat perubahan di komunitas dengan melibatkan masyarakat aras bawah untuk mampu melakukan kontrol. Melalui pendekatan partisipatif, kesadaran kritis masyarakat akan terbangun melalui dialog, pendekatan masalah dan refleksi kritis. Proses yang partisipatif juga memastikan bahwa tidak ada dominasi di dalamnya, ruang demokratisasi dibuka seluas-luasnya, dan setiap orang bisa menyampaikan pandangannya. Peneliti dalam hal ini adalah fasilitator bertugas menjaga proses berlangsung sesuai dengan tujuan yang hendak dicapai. Data-data yang dikumpulkan, baik primer maupun sekunder, pun dengan kesepakatan dan sepengetahuan narasumber dalam diskusi.

\footnotetext{
8 Wilayah riset aksi partisipatif di Biak, Sorong, Jayapura, Keerom, Wamena dan Merauke.
} 
Berdasarkan pengalaman ketika membuat metode alur waktu bersama kelompok perempuan di sebuah kampung di Keerom, para narasumber tidak memiliki informasi mendalam tentang peristiwa pengambilalihan tanah ulayat mereka karena dalam adat setempat, keputusan terkait hak ulayat hanya melibatkan laki-laki. Sehingga kemudian disepakati bersama untuk menghadirkan bapak tiom (ketua adat) dalam diskusi, untuk menjelaskan kronologis peristiwa pengambilalihan tanah ulayat masyarakat adat Keerom oleh P. T. Perkebunan Nusantara (PTPN) II untuk pembukaan kebun kelapa sawit.

Penelitan aksi partisipatif sekaligus kritik terhadap penelitian yang bersifat konvensional, yang mana cenderung memperlakukan narasumber sebagai sumber informasi. Wawancara dilakukan oleh peneliti (umumnya berasal dari luar komunitas) dengan menggunakan panduan pertanyaan tertentu dan narasumber yang menjawabnya dengan pasif sesuai daftar pertanyaan. Meskipun hasil penelitian untuk tujuan positif, namun prosesnya tidak memberi ruang kepada narasumber untuk menyampaikan pandangan kritis, tidak ada refleksi dan ruang untuk saling mendukung transformasi yang berbasis pada kepentingan komunitas. Narasumber hanya ditempatkan sebagai objek penelitian. Sementara jalan keluar persoalan mereka bergantung pada analisis yang dibangun oleh peneliti.

Dalam jangka panjang, pendekatan partisipatif mampu menumbuhkan kesadaran baru dalam masyarakat untuk membebaskan diri dari kungkungan nilai sosial-budaya yang membelenggu. Dalam konteks budaya patriarki, perspektif HAM dan feminis digunakan untuk mengubah cara pandang masyarakat yang sub-ordinat terhadap perempuan agar menjadi lebih adil dan setara. Ketika dalam masyarakat sudah tumbuh kesadaran bahwa keberadaan mereka adalah sebagai manusia dan subjek dalam 
kehidupan bermasyarakat, maka dengan sendirinya mereka akan merumuskan persoalan yang dihadapi, bagaimana jalan keluar dan langkah apa yang bisa dilakukan sesuai kemampuan mereka sendiri. Di sinilah masyarakat akan menjadi agen perubahan dan bukan lagi sebagai objek perubahan.

Proses yang partisipatif juga akan memastikan pengembangan potensi berbasis komunitas yang berkelanjutan. Hal ini berangkat dari pandangan bahwa perubahan masyarakat di komunitas tidak bisa dilepaskan dari media budaya lokal. Meski di satu sisi, ada budaya lokal yang bersifat menghambat (dan ini yang perlu direvitalisasi), namun sisi lain ada nilai-nilai budaya yang bersifat positif dan bisa menjadi potensi. Sehingga ketika melakukan riset, penting juga untuk melihat inisiatif-insiatif lokal yang dikembangkan masyarakat untuk bisa digali kembali dan dikelola lebih baik. Optimalisasi pemanfaatan kapasitas dan sumber daya lokal (seperti pengetahuan, ketrampilan budaya dan pengalaman-pengalaman) merupakan salah satu upaya menghargai kapasitas masyarakat sekaligus untuk menjaga proses keberlanjutan program di komunitas.

Berefleksi dari pengalaman Dokter Henk W. A. Voorhoeve (2009), seorang dokter ahli anak yang bekerja di Papua pada tahun 1960-1962, ia mengatakan bahwa, kebutuhan pelayanan kepada masyarakat seharusnya datang dari keinginan masyarakat itu sendiri, kemudian didukung dan dikembangkan oleh mereka sendiri. Prinsip ini dinilai sebagai satu keberhasilan dalam program kesehatan dasar di Papua dalam kurun waktu tersebut. Prinsip ini selaras dengan pandangan Cicely Williams, seorang ahli anak dunia pertama, yang menyatakan bahwa "pelayanan yang baik adalah pelayanan yang sesuai dengan kebutuhan dan sumber daya yang dimiliki masyarakat" (Verhve dan Voorhoeve 2009)

\section{- Berorientasi pada Aksi}

Setelah perumusan persoalan dan refleksi, proses dilanjutkan dengan menyusun agenda 
bersama. Agenda disesuaikan dengan kebutuhan masyarakat, misalnya pemulihan trauma, pengobatan bagi korban KDRT, peningkatan keterampilan diri (life-skills) atau membangun jaringan untuk memperkuat program yang dijalankan di komunitas. Sehingga, penelitian tidak berhenti pada membuat laporan dan publikasi hasil riset; namun berorientasi pada menjalankan aksi untuk perubahan narasumber dan komunitas. Aksi di komunitas bisa dimulai dengan menyampaikan laporan singkat dan dokumentasi (foto atau film) yang dihasilkan, kepada narasumber, tokoh adat, tokoh agama dan aparat pemerintahan di kampung. Hal ini penting untuk mendorong keterlibatan laki-laki dalam aksi komunitas, agar terjadi transformasi perilaku budaya menjadi lebih adil gender. Membangun kesadaran bahwa persoalan-persoalan yang disampaikan bukan semata persoalan perempuan, namun merupakan persoalan bersama sehingga membutuhkan kerja sama semua pihak untuk jalan keluar. Hasil-hasil dialog bisa jadi masukan untuk merumuskan program pemberdayaan kampung, dengan menggunakan dana-dana desa atau program-program Otsus di kampung.

Berangkat dari pengalaman kerja di Papua, langkah aksi bersama di komunitas, mencakup:

- Pengorganisiran, termasuk di dalamnya adalah membentuk kelompok-kelompok baru, seperti kelompok pendamping kampung (community organizers), koperasi perempuan, kelompok noken, kelompok belajar aksara, dan sebagainya.

- Menjalankan program yang sudah disepakati bersama, membangun ruang belajar sebagai wadah untuk bertemu, bekerja dan berdiskusi, termasuk proses pengembangan/penguatan potensi lokal.

- Advokasi dan membangun jaringan, bisa berupa dialog-dialog dengan aparat kampung, distrik dan kabupaten/kota terkait proses akses layanan/program yang 
tersedia untuk komunitas. Hal lainnya yang juga penting adalah, akses keadilan dan pemulihan untuk perempuan korban kekerasan, termasuk di dalamnya adalah pemeriksaan medis.

Di tahap pengorganisiran, fasilitator bersama masyarakat mengidentifikasi dan membentuk kelompok-kelompok baru yang bertugas menjadi pengorganisir komunitas, sebagai fasilitaror/pendamping untuk menjalankan program-program yang telah disusun bersama. Pengorganisir lokal bisa dari kelompok narasumber maupun kelompok muda yang diperkuat kapasitasnya secara khusus, melalui pelatihan-pelatihan. Pelibatan kapasitas lokal penting untuk menjaga keberlangsungan dan keberlanjutan program di komunitas.

Pengorganisasian juga berarti membangun wadah, ruang atau rumah untuk menjalankan berbagai aktivitas dan proses bersama sebuah komunitas. Proses pengorganisiran berarti bahwa: a) Satu kelompok masyarakat tertentu pertama kali harus mengidentifikasi adanya suatu keinginan bersama untuk melakukan sesuatu dalam rangka memecahkan masalah-masalah penting yang mereka hadapi. Sehingga mereka juga harus mengidentifikasi apa saja masalah penting itu; b) Kelompok masyarakat ini mulai merencanakan suatu strategi bersama mengenai tindakan-tindakan apa yang mereka harus lakukan dan bagaimana cara melakukannya; c) Kelompok kemudian mendaftarkan apa saja kemampuan yang mereka miliki, apa saja kekuatan dan kelemahan mereka dan, jika perlu, apa saja keterampilan dan sumberdaya lain yang masih perlu mereka adakan; d) Kelompok itu telah tiba pada tahap mulai melaksanakan semua rencana mereka sesuai dengan perkembangan yang mereka hadapi (Tan dan Topatimasang 2004). 
Secara ringkas langkah penelitian aksi partisipatif adalah sebagai berikut: (1) Pemetaan masalah; (2) Riset partisipatif; (3) Menyusun agenda aksi; (4) Menjalankan aksi komunitas; (5) Advokasi dan membangun jaringan; (6) Refleksi: merumuskan perubahan sosial sejak awal hingga akhir proses. Langkah-langkah tadi sekaligus menunjukkan perbedaan PAR dengan bentuk penelitian sosial lainnya. Pertanyaannya, mengapa perlu membangun metodologi yang partisipatif untuk perempuan Papua?

Menurut penulis, dalam konteks Papua di mana konflik terus berjalan, belum ada komitmen serius dari negara untuk menghentikan kekerasan yang terus berlangsung. Sementara layanan-layanan pemerintah tidak berjalan optimal dalam berbagai aspek, terutama di wilayah-wilayah konflik; baik daerah yang mengalami konflik secara langsung maupun daerah yang terkena dampak konflik. Lumpuhnya layanan pemerintah, minimnya sarana dan prasana kebutuhan dasar bagi masyarakat terutama kesehatan dan pendidikan, mendorong perlunya sebuah terobosan inovatif yang mampu menggerakkan solidaritas di akar rumput, menggerakkan aksi-aksi bersama di tingkat lokal melalui dialog-dialog dengan pemerintah lokal (desa atau distrik), serta membangun jaringan yang efektif dengan organisasi masyarakat sipil.

Melalui proses ini kita bisa belajar bahwa untuk merumuskan kerangka kerja bagi pemulihan dan pemberdayaan perempuan Papua di akar rumput perlu dimulai dengan keterlibatan perempuan sejak awal. Sehingga, program-program yang disusun memiliki keberpihakan yang jelas pada kepentingan perempuan. Dimulai dari jenis program yang diusulkan, implementasi dan manfaatnya berguna untuk pemulihan dan pemberdayaan perempuan. Pendekatan partisipatif menjadi kunci karena masalah yang diteliti bukan berupa sesuatu yang terukur secara kuantitatif, melainkan merupakan situasi dan persoalan yang terus berkembang dan punya dampak berkelanjutan dari tindak 
pelanggaran HAM di masa lampau, sehinga menyebabkan munculnya kekerasan baru di masa sekarang. Ruang narasumber untuk menyampaikan apa yang mereka alami dan apa yang perlu dilakukan untuk memulihkan diri mereka merupakan hal yang penting dalam metode ini.

Meskipun data riset aksi partisipatif lebih bersifat kualitatif; namun bukan berarti data-data dan analisis kuantitatif tidak digunakan dalam riset PAR. Penggunaan data dan analisis kuantitatif merupakan alat bantu untuk menjelaskan keluasan persoalan, namun tidak boleh mengurangi persoalan utama yang faktual terjadi. Dalam konteks inilah, secara khusus $\mathrm{PWG}^{9}$ mengembangkan alat penelitian aras bawah yang mencerminkan komitmen untuk melibatkan perempuan sebagai narasumber sekaligus sebagai agen perubahan dengan menggunakan pendekatan feminis dan keadilan transisi.

Penelitian ini terutama diharapkan mampu memberi penguatan kepada perempuan korban yang mengalami kekerasan, memfasilitasi proses pemulihan dan pemberdayaan komunitas, membentuk relasi yang dinamis dan solidaritas antar-sesama perempuan, laki-laki, kaum muda dan anak-anak di dalam komunitas. Proses ini juga berkontribusi pada penguatan jaringan perempuan Papua secara luas. Pertemuan pengalaman yang sama di setiap wilayah penelitian membentuk semangat, solidaritas, dan jaringan antarsesama perempuan korban.

\section{- Membangun kesadaran dan meningkatkan pengetahuan bagi perempuan}

Dalam sebuah sesi diskusi di sebuah kampung di Jayapura, seorang perempuan peserta memberikan komentar berikut:

\footnotetext{
${ }^{9}$ Secara lengkap hasil penelitian bisa dilihat dalam buku Sa Ada di Sini: Suara perempuan Papua menghadapi konflikyang tak kunjung usai, Papua Women Working Group (PWG). Publikasi Asia Justice and Rights (AJAR), Jakarta, 2017.
} 
"Saya terima kasih karena ingatan saya yang dulu-dulu bisa kembali dan saya merenungkan kembali cukup sedih. Yang kedua, pensil yang saya sudah buang dari tahun 1967 tapi kemarin dan hari ini saya pegang kembali di umur 62 tahun. Saya ambil pensil ulang lagi saya gambar dan tulis jadi saya terkesan itu yang saya minta ${ }^{10}$ terima kasih banyak."11

Seorang peserta di Keerom menyampaikan hal serupa bahwa mereka mendapat pengetahuan baru dari proses penelitian ini,

"dari pertemuan ini yang tadinya kita merasa tidak bisa, sampai tempat itu di belakang, di belakang dapur saja, yang di depan itu bapak-bapak karena adat di sini begitu. Tapi dengan pertemuan dua hari ini saya merasa kita dilatih untuk bisa bicara..."12

Proses ini juga memberi pengetahuan baru bagi perempuan, di mana selama ini mereka merasa dikucilkan dari sumber-sumber informasi pembangunan, programprogram pemerintah yang tersedia dan peruntukan serta bagaimana mengaksesnya. Adanya kesadaran baru menjadi titik berangkat bagi perempuan untuk membentuk sebuah kelompok/jaringan dalam kampung yang bisa bekerja sama menjalankan agenda aksi. Seorang ibu di Sorong menyampaikan kesannya mengikuti PAR ${ }^{13}$ :

“awalnya merasa lucu seperti anak-anak karena disuruh menggambar peta tubuh, tetapi setelah berproses mereka sadar bahwa proses bermain itu bisa menyimpulkan masalah yang terjadi di kampung yang mereka tidak ketahui bahwa itu adalah masalah mereka, ada kesadaran terbangun."

Seorang perempuan lain menambahkan terkait pentingnya tindak lanjut untuk menyelesaikan masalah yang sudah mereka identifikasi bersama, dia menyampaikan bahwa:

"kami harap ada ruang bagi perempuan untuk belajar bersama, dan agar proses ini tidak berhenti sekarang..kalau memungkinkan, harus ada kegiatan lanjutan agar kami perempuan bisa mendapatkan informasi baru dan mereka dan mereka yang belum tahu jadi tahu."

Setelah proses penelitian, perempuan di Kampung Maibo, Sorong, bersama

\footnotetext{
10 'Minta terima kasih' maksudnya adalah 'mengucapkan terima kasih'. Di Papua biasa mengatakan "minta terima kasih" dan bukan "mengucapkan terima kasih".

${ }^{11}$ Laporan lapangan Magdalena Kafiar, fasilitator Jayapura, Februari 2016.

12 Laporan lapangan Magdalena Kafiar, fasilitator Keerom, Mei 2017.

13 Laporan lapangan Alfonsina Baru dan Alm. Linda Asem, fasilitator Sorong, Februari 2016.
} 
fasilitator lokal menyampaikan hasil penelitian, khususnya permasalahan utama yang mereka hadapi kepada kepala kampung dan aparat desa, dalam sebuah pertemuan di tingkat kampung. Kelompok perempuan juga mengundang perwakilan dari DPR Papua Barat dan Badan Pemberdayaan Perempuan dan Anak Kabupaten Sorong, untuk hadir dalam pertemuan. Dua isu utama yang dibahas adalah:

a) Partisipasi perempuan dalam penyusunan program kampung dan manfaat yang diperoleh perempuan dari program yang tersedia,

b) Masalah kesehatan, air dan transportasi. Permasalahan ini dibahas dan dicarikan jalan keluar bersama dengan memastikan suara perempuan dan progam yang ditujukan untuk kebutuhan perempuan masuk dalam program kampung Maibo dan dalam usulan program tahun berikutnya. ${ }^{14}$

\section{- Membangun Solidaritas Perempuan menuju Advokasi Kebijakan}

Membentuk lingkar/kelompok belajar bagi perempuan di setiap lokasi penelitian, menjadi wadah bagi para perempuan untuk menjalankan program-program untuk perubahan di kampungnya. Meskipun mereka tinggal sekampung, namun belum ada pertemuan yang membuat mereka saling mengenal dan terbangun kesadaran secara kolektif. Bagi mereka proses penelitian partisipatif sangat berguna bagi mereka karena perempuan bisa duduk bersama, berdiskusi, berbagi cerita dan informasi satu dan yang lain, merupakan hal yang berguna bagi mereka masing-masing. Bahkan ada yang berkomentar bahwa dalam pertemuan itu mereka benar-benar bisa saling mengenal, sehingga muncul rasa saling kenal mendalam dan solidaritas satu sama lain tumbuh di antara mereka.

14 Catatan lapangan Selviana Yolanda, April 2017. 
Advokasi jangka panjang oleh jaringan perempuan Papua dalam hubungan yang kuat dengan kelompok perempuan di akar rumput maupun dengan pengambil kebijakan menjadi hal yang penting. Hasil-hasil penelitian di tingkat komunitas dapat tersampaikan kepada pemerintah daerah (bupati/walikota dan gubernur) dan DPR Papua dan Papua Barat hingga ke tingkat nasioal. Temuan Papua Women Working Group menyebutkan bahwa persoalan utama di level pemerintah adalah tidak ada kemauan politik yang kuat untuk menyelesaikan persoalan perempuan.

Dalam era otonomi khusus Papua, hampir tidak ada kebijakan yang berpihak pada perempuan. Program-program khusus dari dana Otsus belum optimal menjangkau kebutuhan perempuan-perempuan di kampung. Otonomi Khusus memberikan kesempatan bagi orang Papua, namun kebanyakan laki-laki yang mengakses bantuanbantuan yang tersedia.

Peserta yang hadir dalam musyawarah kampung (muskam) dan musyawarah perencanaan pembangunan (musrembang) didominasi oleh laki-laki, hampir tidak ada perempuan yang dilibatkan. Seperti yang disampaikan oleh seorang mama dari distrik Kurulu, Wamena. Ketika kami sedang membahas akses perempuan pada dana-dana Otsus 30\% yang diperuntukkan bagi perempuan di kampung, ia mengatakan:

"kami tahu saja kalau ada dana PKK 10 juta sampai di tangan kepala kampung, penggunaan tidak, karena yang jadi ketua PKK isteri kepala kampung, jadi kami tidak tahu penggunaannya... katanya ada dana untuk noken memang kita dikasih dari ketua PKK untuk buat noken tapi selanjutnya hasil jualan noken tidak pernah kasihtau ke kami... selama ini tidak ada sosialisasi, hanya laki-laki saja di kantor desa yang ikut pertemuan, kami sama sekali tidak pernah ikut. Kami tahu pergi ke kebun, pulang urus wam [babi]."15

Pelibatan perempuan dalam proses muskam, mestinya tidak hanya sebatas kuota jumlah yang hadir, namun memastikan perempuan berpartisipasi mengajukan usulan,

15 Catatan lapangan Selviana Yolanda saat penelitian di Wamena, 4-5 Desember 2015. 
kritik berdasarkan kondisi di lapangan. Usulan program bukan sekedar berdasarkan keinginan, namun apa yang dibutuhkan perempuan berdasarkan analisis kebutuhan lapangan. Seorang perempuan peserta penelitian aksi partisiatif di Kampung Sota, Distrik Sota, Kabupaten Merauke juga menyampaikan kisah yang serupa:

"dalam Muskam 2015-2016 tidak ada dana untuk perempuan, dari PKK mengusulkan namun dari pihak kepala kampung bilang, tidak bisa karena tidak ada pengurus. Usulan mama-mama waktu itu adalah kegiatan PKK... bawa mesin jahit datang tapi tidak ada kursus menjahit, sehingga kasih tinggal begitu saja."

Aparat kampung di Kampung Sota, yang dikonfirmasi terkait hal ini mengatakan,

"ketika kita tanya ibu-ibu dorang apa yang mau diusulkan, dorang bilang mau menjahit, jadi kita usulkan pembelian mesin jahit. Tapi begitu barang itu datang trada yang tahu menjahit, akhirnya barang itu kas tinggal begitu saja. Sekarang ibu-ibu dari transmigrasi (pendatang) dorang yang pakai."

Setelah penelitian aksi partisipatif berlangsung, mulai tumbuh kesadaran kritis perempuan terhadap berbagai persoalan kampung. Mereka mengidentifikasi sejumlah persoalan utama yang mereka hadapi, mulai dari persoalan kebutuhan dasar seperti kesehatan, perubahan pola makan akibat ancaman-ancaman kehilangan sumber kehidupan (tanah dan hutan) sampai kebijakan taman nasional dan pembangunan. Selain itu, perempuan mulai menyadari pentingnya partisipasi perempuan dalam penyusunan kebijakan dan mendapatkan hak mereka sesuai dengan ketentuan Undang-Undang.

Tim fasilitator yang mendampingi proses penelitian di Distrik Sota, kemudian memfasilitasi pertemuan-pertemuan lanjutan untuk merumuskan agenda untuk perempuan di kampung itu. Salah satu tindak lanjut bersama adalah membentuk kelompok perempuan Kampung Sota. Kelompok ini akan menjadi wadah untuk membahas pemasaran hasil kerajinan perempuan seperti toware (tas), madu dan kerajinan perempuan lainnya. Bersama tim fasilitator, kelompok perempuan juga menyampaikan hasil diskusi mereka dengan kepala kampung dalam sebuah dialog 
kampung.

Awalnya, sikap kritis yang disampaikan kelompok perempuan dipandang secara negatif oleh kepala kampung, namun setelah dialog berlangsung, kepala kampung menyepakati bahwa perempuan perlu terlibat dalam program kampung. Hal ini dimulai dengan mempercayakan kepada perempuan untuk menyediakan makanan lokal dalam acara-acara resmi di kampung. Selain itu, mereka menyepakati kelompok perempuan akan dilibatkan secara penuh dalam proses musyawarah kampung. ${ }^{16}$

\section{- Menggalang dukungan komunitas menuju advokasi layanan bagi korban}

Fasilitator lapangan Wamena menuliskan pengalaman mereka ketika menyampaikan persoalan-persoalan kunci yang dialami oleh "mama-mama janda 17 " dan rencana kegiatan (aksi) kepada para ketua adat, tokoh gereja dan aparat kampung di Manda, Wamena.

Pada bulan Oktober 2016, kami bertemu dengan tokoh adat, tokoh gereja dan kepala suku di Kampung Manda. Kami menyampaikan rencana pembangunan rumah belajar dan kegiatan-kegiatan lain seperti advokasi KTP dan bantuan kesehatan untuk Mama-mama. Kami mendapat sambutan baik dari tokoh adat dan gereja. Hal ini baik untuk seorang Bapak yang merupakan tokoh gereja mengatakan, sangat setuju kegiatan seperti ini bisa membantu kami untuk menghilangkan rasa sakit kami dengan begitu kegiatan yang dilakukan bisa membuat kami bisa berusaha belajar berjuang dalam hidup kami walaupun ada luka. Seorang Bapak dari Gereja Baptis juga bilang: "kegiatan yang kalian lakukan ini sangat baik, karena di sini banyak juga angka kekerasan rumah tangga dan kekerasan dari militer sering terjadi, sehingga ini juga sangat membantu kami, dan untuk mama-mama ini perlu lakukan banyak kegiatan agar mereka bisa merasa nyaman dan ada perubahan dari rasa takut mereka. Saya sebagai hamba Tuhan setempat sangat setuju dengan kegiatan ini" di akhir kegiatan, para tokoh gereja sepakat memberikan lahan gereja untuk dibangun rumah belajar bagi mama-mama. ${ }^{18}$

Setelah pertemuan, fasilitator bersama perwakilan komunitas kemudian

\footnotetext{
${ }^{16}$ Catatan lapangan Selviana Yolanda dan Betty Gebze dan Maria Kanden. Merauke, April 2017.

17 Sebutan untuk komunitas-komunitas di Wamena, di mana mayoritas di dalamnya terdiri atas perempuan dan anak-anak. Mama-mama yang menjadi kepala keluarga karena suami mereka meninggal karena sakit, dibunuh aparat keamanan saat terjadi konflik atau yang pergi begitu saja menelantarkan keluarga.

${ }^{18}$ Laporan lapangan tim fasilitator Wamena: Lena Daby, Mully Wetipo, Margareta Wetipo. Yayasan Humi Inane, Maret 2017.
} 
melakukan pendekatan kepada instansi pemerintah terkait di level Kabupaten Jayawijaya untuk pendataan administrasi kependudukan, khusus bagi mama-mama yang belum memiliki. Tim fasilitator lokal kemudian bekerja sama dengan Dinas Kependudukan Kabupaten Jayawijaya melakukan perekaman data mama-mama untuk dibuatkan E-KTP dan Kartu Keluarga, di mana mereka sendiri sebagai kepala keluarga; jika sebelumnya untuk pencatatan kartu keluarga mereka mengikut kepada keluarga saudara laki-laki mereka karena ketentuan bahwa laki-laki adalah kepala keluarga. Diharapkan dengan mengurus kelengkapan administrasi kependudukan, mama-mama bisa dengan mudah mengakses program Papua Sehat, bantuan-bantuan Otsus dan program lain yang disediakan pemerintah. Semua langkah dan aksi yang akan dilakukan, dibahas dan mendapat masukan dari komunitas. Dengan demikian, kegiatan yang dilaksanakan sudah sesuai dengan kebutuhan dan masyarakat berpartisipasi dalam pelaksanaannya.

\section{- Dokumentasi visual sebagai "komunikasi kreatif"}

Menurut pengalaman penulis, komunikasi kreatif menjadi penting dalam penelitian aksi partisipatif, dengan mengombinasikan tulisan, tuturan lisan, dan dokumentasi visual seperti foto dan film dalam proses dan penyusunan hasil penelitian. Secara pribadi, penulis memiliki ketertarikan menggunakan dokumentasi visual untuk mendukung pengembangan komunitas. Dalam konteks pedesaan, atau wilayah-wilayah yang letaknya jauh, foto dan film, menjadi efektif untuk memberikan gambaran tentang persoalan yang dihadapi dan konteks. Publik dan pemerintah bisa punya bayangan dan melihat apa yang terjadi dalam satu wilayah. Hal ini membantu penyadaran publik terhadap persoalan yang terjadi, sekaligus mendorong solidaritas dan lahirnya ide-ide baru guna membantu pemulihan korban dan jejaring dalam aksi komunitas. 
Melalui metode foto bercerita, narasumber bisa menunjukkan kondisi kehidupannya sehari-hari, misalnya apa yang dia kerjakan, sumber-sumber kehidupannya, lingkungan tempat tinggal, keluarga dan kondisi rumah serta tempattempat yang memberi arti khusus dalam kehidupannya. Mereka bisa menjelaskan fotofoto yang dihasilkan kepada sesama peserta riset. Metode seperti ini mendorong pembelajaran bersama di antara peserta penelitian, bisa saling mengenal satu sama lain dan melatih kemampuan berbicara di depan forum. Hal lain yang tak kalah penting adalah menjadi ruang berekspresi bagi para narasumber. Sementara, film dokumenter bisa memberi gambaran yang utuh tentang sebuah persoalan berdasarkan kesaksian para narasumber. Biasanya, pesan-pesan yang ingin disampaikan dapat dengan mudah dipahami oleh penonton. Dengan demikian, produk foto dan film bisa menjadi alat advokasi yang efektif untuk perubahan kebijakan.

Anggota komunitas perlu diperkuat kapasitasnya dalam hal membuat dokumentasi visual agar dalam jangka panjang mereka mampu memanfaatkan teknologi untuk kebutuhan sehari-hari, seperti menjual komoditi yang dihasilkan, promosi potensi wilayah, dan bisa juga untuk tujuan advokasi yaitu menyampaikan kepada pemerintah kondisi sarana-prasarana pembangunan di kampung mereka. Tentunya, hal tersebut diselaraskan dengan media sosial yang berkembang saat ini. Selain menggunakan foto atau film, komunikasi kreatif bisa melalui media drama, menulis lagu, atau media budaya lain yang relevan.

\section{Hambatan dan Keterbatasan}

\section{- Waktu dan jangkauan}

Sebagai sebuah pendekatan, metode penelitian partisipatif memberi ruang seluas- 
luasnya kepada narasumber dalam membahas sebuah persoalan dan merumuskan aksi. Idealnya setiap kegiatan dihadiri oleh paling banyak lima belas orang, agar memastikan setiap orang berkesempatan berpartisipasi dalam proses ini. Untuk bisa menerapkan semua metode, dibutuhkan empat hingga lima hari pertemuan. Dengan demikian, secara teknis metode ini sulit untuk menjangkau narasumber dan komunitas yang lebih banyak dan luas, jika tidak didukung dengan ketersediaan waktu dan biaya yang cukup memadai.

Waktu yang terbatas menyebabkan tidak semua langkah-langkah metodologis bisa diterapkan sesuai dengan jadwal yang direncanakan, apalagi di komunitas akar rumput. Di sini, perempuan memiliki beban kerja yang tinggi. Akibatnya, proses penelitian harus disesuaikan dengan ketersediaan waktu mereka.

\section{- Bahasa}

Kendala bahasa juga menjadi faktor keterbatasan dalam proses ini. Berdasarkan pengalaman bekerja di Papua, terutama di wilayah pedalaman, tidak semua peserta mengikuti proses dengan baik karena kendala bahasa. Di beberapa kampung di wilayah perbatasan Papua dan Papua Nugini, masyarakatnya menggunakan bahasa Pijin (bahas resmi Papua Nugini), sehingga mereka kesulitan dalam memahami bahasa Indonesia. Demikian pula di wilayah pegunungan yang lebih terbiasa menggunakan bahasa lokal. Untuk menjembatani hal ini, dibutuhkan penerjemah, dan sebaiknya lebih dari satu orang agar peserta bisa aktif mengikuti proses dan peserta juga tidak segan mengeluarkan pendapat.

\section{- Penguatan Kapasitas Fasilitator Lokal}

Pengorganisasian membutuhkan orang lokal yang paham budaya dan bahasa setempat supaya bisa melakukan penguatan keterampilan pada fasilitator lokal untuk 
mengorganisir, bagaimana menggali persoalan, menemukan pola-kaitan satu persoalan dengan yang lain, merumuskan dan menganalisis, serta membuat laporan singkat. Situasi konflik di Papua, mau tidak mau sangat berpengaruh pada masyarakat; baik korban langsung maupun yang terpapar oleh dampak konflik. Fasilitator lokal mungkin adalah orang yang mengalami kekerasan dan trauma panjang. Karenanya, dibutuhkan kemampuan trauma healing yang bersifat kolektif, maupun teknik self-care.

\section{- Konfirmasi hasil penelitian dengan pengambil kebijakan}

Penelitian ini merupakan pandangan para narasumber di akar rumput, dan untuk memastikan (konfirmasi) hasil penelitian perlu dilakukan dialog dengan aparat pemerintah. Dalam hal ini, apparat pemerintah yang dimaksud adalah instansi terkait dengan isu yang dibahas. Namun, berdasarkan pengalaman di Papua pula, proses ini sulit dilaksanakan karena tidak ada kesediaan waktu aparat pemerintah untuk membahas hasil riset. Jalan keluar yang kemudian dilakukan adalah menyampaikan laporan penelitian ini kepada pemerintah untuk membahas permasalahan kunci dan rekomendasi dari penelitian ${ }^{19}$.

Secara ringkas, metode aksi partisipatif yang dikembangkan oleh PWG dalam penelitian di Papua ${ }^{20}$ adalah sebagai berikut:

1. Alur Waktu: Metode ini dikembangkan dengan fokus memahami sejarah lokal dan peristiwa penting yang terjadi serta dampaknya pada kehidupan perempuan dan komunitas. Proses ini menghasilkan sebuah cerita sejarah kolektif dengan sudut

\footnotetext{
${ }^{19}$ PAW, Komnas Perempuan bersama dengan jaringan perempuan di Tanah Papua menggelar dialog terkait tujuh Laporan Stop Sudah dan launching Laporan Sa Ada di Sini di kantor gubernur Papua, pada Juni 2017. Selanjutnya, dialog dengan menghadirkan kementerian terkait dan staf khusus kepresidenan dilaksanakan di Kantor LIPI Jakarta pada Oktober 2018.

${ }^{20}$ Lebih lengkap mengenai metode Penelitian Aksi Partisipatif bisa dilihat dalam buku Melepas Belenggu Impunitas: Sebuah panduan untuk pemahaman dan aksi bagi perempuan penyintas. Publikasi Asia Justice And Rights, Jakarta (2015).
} 
pandang yang lebih luas daripada cerita perseorangan saja. Peserta juga mendapatkan kesadaran baru tentang perubahan yang terjadi dalam diri mereka dan komunitas.

2. Sungai (Kali) Kehidupan: Peserta menggambar sebuah sungai (kali) yang menjelaskan kisah-kisah penting dalam perjalanan hidup mereka, baik kisah pahit maupun bahagia. Peserta juga membuat simbol dirinya yang mengacu pada benda di sekitar lingkungan alam yang menjadi sumber kekuatan mereka. Dengan proses ini kita mendapat profil kehidupan narasumber dan nilai serta ikatan mereka dengan alam sekitar.

3. Peta Kampung: Para peserta menggambar peta kampung mereka, menandai lokasi rumah, kebun, sumber air bersih, sarana layanan pemerintah, tempat keramat, kebun, tempat berburu dan mengambil hasil hutan, tanah marga dan lokasi kekerasan atau lokasi penting lainnya yang menjadi bagian pengalaman mereka. Peserta diajak bercerita bagaimana jangkauan mereka pada sumbersumber penghidupan, dan perubahan-perubahan yang terjadi; bagaimana mereka mengakses layanan pemerintah (kesehatan dan pendidikan); program dan bantuan yang tersedia di pemerintahan, layanan publik termasuk administrasi kependudukan, kondisi sarana dan prasarana pembangunan, termasuk transportasi dan pasar. Komunitas seperti apa yang mereka impikan di masa depan.

4. Peta Tubuh: Perempuan bercerita masalah kesehatan yang dialaminya dan penyebab, juga sakit yang diderita oleh komunitas; bagaimana mereka mengakses layanan kesehatan (rumah sakit/puskesmas, obat, asuransi kesehatan, tenaga kesehatan); apakah ada inisiatif atau pengobatan tradisional yang digunakan 
masyarakat; dan juga bagaimana caranya mengubah tubuh yang sakit menjadi sembuh.

5. Batu Bunga: Menggunakan kerangka hak korban untuk kebenaran, keadilan, pemulihan dan jaminan tak berulang. Dalam proses ini peserta diajak untuk merenungkan hal-hal berikut ini: Apakah kebenaran tentang pengalaman kekerasanku telah diakui? Apakah keadilan telah hadir dalam kehidupanku? Apakah sudah ada pemulihan dalam kehidupanku dan keluargaku? Apakah hidupku kini bebas dari kekerasan? Setelah itu, peserta akan menaruh bunga jika jawaban mereka adalah 'ya'; dan menaruh batu jika jawaban mereka 'tidak'. Peserta pun diundang menjelaskan mengapa mereka menjawab 'ya' dan 'tidak'.

6. Kotak Ingatan: Peserta diminta mengisi sebuah kotak dengan benda-benda yang memberi kenangan pahit dan manis. Mereka juga diminta menulis pengalaman hidup mereka dalam beberapa kartu pos. Dalam sesi pertemuan terakhir, para peserta kemudian diminta menceritakan isi kotak ingatannya kepada peserta yang lain.

7. Foto Bercerita, Bercerita dengan Foto: Para pendamping berkunjung ke rumah peserta untuk membuat foto-foto yang berkisah tentang kisah hidup mereka sesuai informasi yang disampaikan dalam proses PAR. Foto-foto tersebut berupa foto close up, rumah, sumber kehidupan, foto bersama keluarga/tetangga, sumber kekuatan, benda dan lokasi-lokasi dan benda-benda yang memiliki makna khusus. Setelah mengambil foto, para peserta memilih foto yang ingin ditampilkan dan, di dalam pertemuan, peserta berbagi kisah kehidupan masing-masing dari foto yang diambil. 


\section{Penutup dan Rekomendasi}

Sebagai catatan akhir, penulis menunjukkan beberapa poin rekomendasi yang dikeluarkan oleh PWG dalam laporan awal mereka di tahun 2016 (PWG, AJAR dan MAMPU 2016, 20). Catatan itu adalah tentang pengembangan aksi partisipatif bagi perempuan sebagai bagian dari bottom up approach demi merumuskan kerangka kebijakan pembangunan yang partisipatif. Rekomendasi ini penting untuk diperhatikan oleh pembuat kebijakan dan berbagai stakeholder yang terkait dalam perencanaan dan inisiatif pembangunan.

Pertama, memprioritaskan pendekatan partisipatif yang memberdayakan perempuan asli Papua dengan cara memperluas ruang bagi mereka untuk berperan serta dalam perencanaan dan inisiatif pembangunan, antara lain:

- Mengadvokasi pemerintah setempat dan pelaku pembangunan lainnya untuk menggunakan pendekatan partisipatif dan memastikan bahwa perempuan terlibat secara bermakna dalam musyawarah terkait dengan isu-isu pembangunan di semua tingkat.

- Mengusung ide "musrenbang perempuan" kepada pemerintah dan pelaku pembangunan lainnya di tingkat desa. Ini untuk memastikan bahwa perempuan memiliki akses dan dapat ikut serta dalam proses perencanaan.

- Mendorong pemantauan dan dukungan oleh masyarakat sipil untuk memastikan keikutsertaan perempuan dalam proses pengambilan keputusan. 
- Mendukung inisiatif masyarakat sipil untuk memperkuat inovasi dan kesempatan belajar tentang pendekatan partisipatif yang berpusat pada perempuan sebagai metode pengembangan masyarakat dan pemberdayaan perempuan.

Rekomendasi kedua adalah mengkaji dan mendukung penyebarluasan informasi yang baik, antara lain dengan:

- Melakukan upaya advokasi khusus dengan pemerintah setempat untuk mendorong penyebaran informasi tentang bantuan dan layanan yang ada.

- Mengadvokasi pemerintah untuk melakukan transparansi serta penyebaran informasi dan data kepada warga. Ini termasuk membuka ruang bagi dialog antara pemerintah dan warga, termasuk kaum perempuan Papua, di tingkat desa.

- Mencari pelaku reformasi dari dalam pemerintah yang bersedia memfasilitasi aliran informasi dan dialog.

- Meningkatkan akuntabilitas dengan cara memperbaiki akses perempuan Papua atas mekanisme ganti rugi dan penanganan keluhan.

- Memberdayakan masyarakat sipil, khususnya perempuan dalam mengawasi penerapan program dan layanan pembangunan. Contoh di bidang layanan kesehatan termasuk tingkat kehadiran petugas, ketersediaan medical supply, kualitas layanan, dll.

- Menyampaikan hasil penelitian terkait kepada pemerintah setempat dan pembuat kebijakan; serta menggunakannya sebagai platform advokasi. 


\section{Referensi}

Koalisi untuk Keadilan dan Pengungkapan Kebenaran (KKPK). 2014. Menemukan Kembali Indonesia: Memahami empat puluh tahun kekerasan demi memutus rantai impunitas. Laporan diakses dari http://www.kkpk.org.

Dengar Kesaksian Korban Pelanggaran HAM, laporan dipublikasi bulan September.

Komisi Nasional Perempuan (Komnas Perempuan), Kelompok Kerja Perempuan Majelis Rakyat Papua (Pokja Perempuan MRP) dan the International Center for Transitional Justice (ICTJ). 2010. Stop Sudah! Kesaksian Perempuan Papua Korban Kekerasan dan Pelanggaran HAM 1963-2009.

Papuan Women Working Group (PWG). 2017. Sa Ada Di Sini: Suara perempuan Papua menghadapi kekerasan yang tak kunjung usai, laporan riset.

Papuan Women Working Group (PWG), Asia Justice and Rights (AJAR), dan Maju Perempuan Indonesia untuk Penanggulangan Kemiskinan (MAMPU). 2016. Laporan pertama Sa Ada Di Sini: Permasalahan dan Kesempatan Bagi Perempuan Papua dari Persepektif Perempuan Papua.

Peduli Papua. 2015. "Tujuh Wilayah Adat Papua." Community Care Papua, 9 Maret. http://communitycarepapua.blogspot.co.id/2015/03/7-tujuh-wilayah-adat-dipapua-peta.html.

Rathgeber, Theodor. 2006. Peny. Hak-hak Ekonomi, Sosial dan Budaya di Papua Barat: Studi Realitas Sosial dan Perspektif Politik. Publikasi Evangelical Church in the Rhineland, Gereja Kristen Injili di Tanah Papua.

Tan, Jo Hann dan Roem Topatimasang. 2004. Mengorganisir Rakyat: Refleksi Pengorganisiran Rakyat di Asia Tenggara. Yogyakarta: SEAPEC dan Insist Press.

United Nations General Assembly (UNGA). 2008. Report of the working group on the Universal Periodic Review Indonesia, A/HRC/8/23, 14 May.

Verhve, Jan Peter dan Henk W. A. Voorhoeve. 2009. Pelayaan Kesehatan di Papua 19502000. Jayapura: Pemerintah Provinsi Papua, atas izin the Netherlands Society of Tropical Medicine and International Health.

Wandita, Galuh, dkk. 2015. Bertahan dalam Impunitas: Kisah Para Perempuan Penyintas yang Tak Kunjung Meraih Keadilan. Jakarta: Asia Justice and Rights (AJAR). 